a comparatively thick bark which may be impervious to gases, and the role of sodium chloride is doubtful. It is probable that a number of factors-winter temperature, ocean currents, tidal inundation, soil accretion, mechanical composition of soil, exchangeable base and the behaviour of the water table-are all important collectively. Soil conditions vary over relatively narrow limits. Soil $p \mathrm{H}$ varies from about 6 to about 8 over the soil types populated and the water-table fluctuates through only two to three inches. This latter is particularly important, for it means that the horizontal roots and the pneumatophores are above the water-table for considerable periods, and we must abandon the idea that mangrove roots must be bathed in water continually. In the soil water the oxygen content is well below the atmospheric percentage, but carbon dioxide is on the whole higher, and this therefore lends colour to the widely accepted belief in the function of the pneumatophores in aeration. The $\mathrm{Na}+$ and $\mathrm{Cl}-$ contents of soil water and of plants are presented at some length, but unfortunately the statements made in this part of the paper lose much of their force as the basis upon which the percentages are given is not clearly defined.

The third paper gives a very welcome and admirably thorough description of the developmental morphology of $A$. nitida from the young seedling to the mature plant, profusely illustrated by line drawings in some of which, however, it is not always easy to pick out the details referred to in the text. Secondary thickening appears to varying extents in almost all the organs of the plant, and it is particularly interesting that, so far as one can judge from the data presented, thickening begins in the roots before it does in the stems (though this is not, in fact, specifically stated). The pneumatophores (which are said to be negatively geotropic, but may, as Dr. Chapman points out, be positively aerotropic) may be some $35 \mathrm{~cm}$. high by about $8-10 \mathrm{~mm}$. thick, with well-formed lenticels in the above-ground portion. The cortex has numerous large longitudinal air spaces, as has also the corresponding tissue in the horizontal roots from which the pneumatophores arise, but the two systems are apparently separated by a more solid tissue at the base of the pneumatophores. Movement of gases from pneumatophore to horizontal roots must therefore occur by diffusion and not by mass flow. The gas in these air spaces is very much like that in the atmosphere and very different from that found in the soil water. Experimental work shows that of the carbon dioxide exhaled by a pneumatophore, about 50 per cent may come from the respiration of the pneumatophore itself (a figure which should apparently be in fact much higher, since in the experiments the air spaces in the horizontal roots were replaced by an atmosphere containing 10 per cent carbon dioxide applied to the lower end of the pneumatophore from cylinders prepared in advance in Britain; this carbon dioxide content is much larger than that actually found in the air spaces). The respiratory function of the pneumatophore itself must therefore not be overlooked. Further, as Chapman also emphasizes, the pneumatophores carry absorbing rootlets near the soil surface and as soil accretion occurs, these rootlets appear higher up the pneumatophore and therefore nearer the new soil surface. A further important function of the pneumatophores may therefore be the maintenance of a functional absorbing root system.

Dr. Chapman makes it abundantly clear that mangroves will repay intensive study by morpholog. ists, physiologists, geneticists, biochemists and even students of cell-wall problems. In this latter regard, some of the cells in pneumatophores bear peculiar internal buttresses growing into the cell from the wall and recalling the trabeculæ found in the tracheids of some conifers and similar structures in marine algæ like Caulerpa. These iodioblasts, as they may be called, would repay study. All the papers include a very full bibliography and a careful comparison of the writer's work point by point with that of earlier workers in the field, and this makes them, indeed, a veritable compendium of mangrove-lore.

R. D. Preston.

${ }^{1}$ Chapman, V. J., J. Linnean Soc., 52, No. 346 (1944).

\section{EFFECTS OF HEAT ON HUMAN BEINGS}

A $\mathbf{N}$ interesting series of physiological and clinical observations on the effect of the desert climate of Shaiba, southern Iraq, in the summer of 1943, has been reported by W. S. S. Ladell, J. C. Waterlow and M. F. Hudson (Lancet, 491, Oct. 14 and 527, Oct. 21, 1944). Both fit soldiers and cases of the effects of heat were studied. All the fit men lost some weight in the hot weather, especially those who had the highest chloride concentration in their sweat. The measured rate of sweating and the estimated salt intake indicated that subjects with a high concentration of chloride in their sweat (more than 0.3 per cent of sodium chloride) may not always have been in salt balance. Low output of urine, in spite of high water intake, low urinary chloride and raised blood urea, suggested salt-deficiency dehydration.

Twelve cases of hyperpyrexia are recorded and two types of heat exhaustion. The first type occurs, it is suggested, in persons who secrete sweat containing much higher chloride concentrations than the average; their salt intake is insufficient and they become salt-deficient; extra salt might prevent the occurrence of heat exhaustion in these persons. The second type was seen only in the second half of the summer in men unaffected by the heat of the first half; prickly heat accompanied the heat exhaustion, but this type did not have the vomiting and cramps suffered by the first type. The condition of the second type suggested a breakdown of the body's defences against heat. There was salt-deficiency, but no dehydration. It would be worth while to inquire whether the concentration of salt, or of other constituents of the sweat, or the influence of other factors controlling its secretion, could be related in any way to the wellknown variations in susceptibility to the bites of mosquitoes and other biting arthropoda.

Following this article, D. H. G. MacQuaide describes (Lancet, 531, Oct. 21, 1944) two cases of congenital absence of the sweat glands. Both had to be classified as totally unfit for service in the tropics. The author adds an interesting note on the literature relating to congenital ectodermal defects. These include an idrotic group, which is mostly a hair and nail dystrophy found in both sexes and transmitted by either, and an anidrotic group, found mostly in males and probably transmitted by a maternal carrier ; in this latter group are absence of the sweat glands and occasionally of the sebaceous glands, dental dysplasia and other conditions of the nose, skin and hair. No cases belonging to this group are known in Negroes or Latin races. G. LAPAGE. 